\title{
Seasonal and spatial mobility patterns of rose shrimp Aristeus antennatus in the Western Mediterranean: results of a long-term study
}

\author{
F. Sardà ${ }^{1, *}$, F. Maynou ${ }^{1}$, L. Talló ${ }^{2}$ \\ 'Institut de Ciències del Mar, CSIC, Plaça del Mar, s/n, E-08039 Barcelona, Spain \\ ${ }^{2}$ Fishers' Association, Passeig Joan de Borbó, 54, E-08039 Barcelona, Spain
}

\begin{abstract}
The mobility pattern of the deep-water shrimp Aristeus antennatus (Risso, 1816) was studied off the Catalan coast (NW Mediterranean) over a 10 yr time scale. The study area comprises upper and middle slope depths and submarine canyons. This extended data set 1780 observations corresponding to 845 days over 10 years) confirmed and allowed refinement of previous hypotheses of $A$. antennatus large-scale mobility patterns. Our results show that this species follows a well-defined seasonal mobility pattern. It is more abundant on open slope areas (around $800 \mathrm{~m}$ depth) in late winter and spring. The larger fraction of the population moves in submarine canyons in late summer and autumn, towards shallower depths (around $500 \mathrm{~m}$ ). This general pattern of population mobility is coupled with important sex and size segregation. Adult females are present year-round throughout the different habitats sampled, while the abundance of males and juvenles is higher in submarine canyons in autumn and early winter. The large-scale mobility pattern of $A$. antennatus is not common in deep-sea species. The relevance of our results is discussed in relation to the deep-water environment and the biological cycle of the species
\end{abstract}

KEY WORDS: Aristeus antennatus - Mobility - Large scale - Temporal scale - Spatial scale - Deep-sea ecology $\cdot$ Mediterranean

\section{INTRODUCTION}

The rose shrimp Aristeus antennatus (Risso, 1816) is a dominant benthic species on the upper and middle slope in the Western Mediterranean and adjacent seas (Cartes \& Sardà 1992, 1993), occurring between 300 and $2000 \mathrm{~m}$ depth (Sardà \& Cartes 1993a, b). Its ecological and biological characteristics are well known (Orsi Relini \& Relini 1979, Sardà \& Demestre 1987, Demestre \& Fortuño 1992, Ragonese \& Bianchini 1992, Bianchini \& Ragonese 1994). The rose shrimp is a target species of the deep-water demersal trawl fishery in the Western Mediterranean and adjacent seas and its population dynamics is relatively well known from a fisheries perspective (Relini \& Orsi Relini 1987, Demestre \& Lleonart 1993, Ragonese \& Bianchini 1996). Aspects of its trophic ecology have also been

\footnotetext{
•E-mail: siscu@icm.csic.es
}

studied (Cartes \& Sardà 1989, Cartes 1994, Maynou \& Cartes 1997). However, there are still problems for a complete understanding of its life cycle and autoecology (Sardà 1993); specifically, the spatio-temporal dynamics of rose shrimp populations is complex, showing important fluctuations. The study of the large-scale dynamics of this deep-water species is also important to gather insight into the general ecology of deep-sea benthic communities (Cartes \& Sardà 1992, 1993).

Tobar \& Sardà (1987) described the seasonal fluctuations of this species along the Catalan coast (NE Spain). Later, Sardà et al. (1994b) made available evidence for different population structures in distinct habitats of the continental slope, between 400 and $700 \mathrm{~m}$. They found that several bio-ecological characteristics, such as mean size of individuals, female maturity stages and sex ratio, varied according to the spatial location of the samples (canyon margins, open slope). The main limitation of the aforementioned stud- 
$1^{\circ} 50^{\prime} \mathrm{E}$

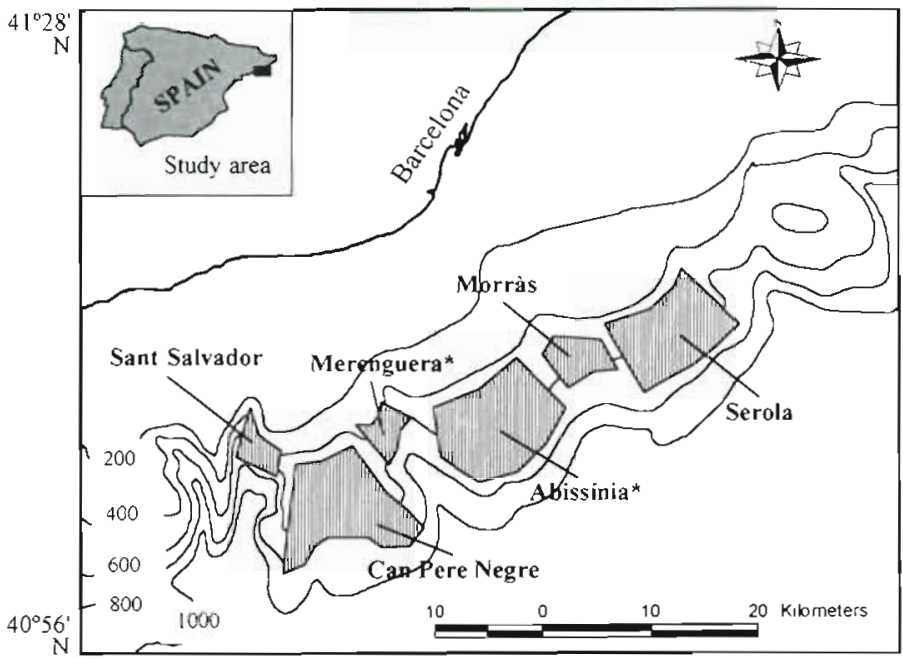

Fig. 1 Location of rose shrimp Aristeus antennatus sampling areas off the Catalan Coast (NW Mediterranean). *Areas where both scientific and commercial trawl samples were obtained ies lies in the short time scale of observation, 1 yr which limited the generalisation of the patterns observed. These studies are valuable, however, as working hypotheses on the space-time dynamics of Aristeus antennatus.

In this paper, the analysis of a 10 yr data set is presented and will be used to test the mobility patterns in this deep-water aristeid shrimp and their persistence through time. We took advantage of the existence of a specialised demersal trawl fleet in the study area targeting the rose shrimp to collect an extended and reliable daily data set over a long time-span and covering differing habitats. The data set based on commercial boat records was complemented with an experimental survey carried out during the study period on a scientific research vessel.

Aristeus antennatus is the first deep-water benthic crustacean (below $500 \mathrm{~m}$ ) for which a large-scale mobility pattern or migratory behaviour has been described, although such phenomena are known for shallow water penaeids (García \& Le Reste 1987) or pandalids (Pandalus borealis; Ouellet \& Lefaivre 1994) The objective of this paper is to show the permanence in time of the seasonal mobility patterns in $A$. antennatus, and to discuss our findings in relation to its life strategy and its deep-water environment.

\section{MATERIAL AND METHODS}

Study area. To obtain reliable daily catch data for a long period of time for Mediterranean species is extremely difficult, given the uncertainty in official catch statistics. Thus, we designed a long-term study to describe the spatio-temporal mobility of Aristeus antennatus from catches of a specialised trawler operating off Barcelona (NE Spain). Only 1 boat was selected in order to keep constant the characteristics of the sampling, such as constancy over time of the skipper, the sampling gear and the sampling procedure. The boat and trawl characteristics are: $24 \mathrm{~m}$ length, $500 \mathrm{hp}$, and Catalan trawl with $70 \mathrm{~m}$ of foat-rope, $600 \mathrm{~kg}$ otter doors and $38 \mathrm{rmm}$ stretch mesh size in the cod end. The skipper of the selected boat was given a specially designed log-book. Each entry (record) of the log-book included, among other items, the exact start and end position of each haul, the catch and the proportion of sizes in the catch. The final data set comprises the daily fishing activity of a representative boat over the period 1986 to 1996 . The data collection was overseen periodically by on-board scientific observers from our research team. The data noted by the skipper in the log-book was crosschecked at random with the official sale bills from the fish market for this commercial boat. The fishing activity encompassed traditional grounds of $\mathrm{B}$ Barcelona, covering upper and middle slope depths of varying bottom morphology (Fig. 1). The fishing grounds known as 'Serola' and 'Abissínia' are located over the slope between 450 and $750 \mathrm{~m}$ depth. The fishing grounds known as 'Morràs', 'Merenguera' and 'Sant Salvador' are located over the heads of canyons cutting the slope (Fig. 1), at 350 to $600 \mathrm{~m}$ depth. Finally, 'Can Pere Negre' is a fishing area of intermediate structure, being a slope area crossed by small canyons and depressions, at depths ranging from 450 to $800 \mathrm{~m}$. Hauls last 2 to 3 h over open-slope fishing grounds, while in the canyons they last about $1 \mathrm{~h}$, due to the complexity of the sea floor.

The distance from the coast to the farthest fishing grounds is $35 \mathrm{~km}$. From the nearest to farthest fishing grounds the distance is $40 \mathrm{~km}$. The total surface of the study area is $750 \mathrm{~km}^{2}$.

Data analysis. A preliminary data analysis was required in order to check for the quality and consistency of the data. The data selected for the final analysis were those obtained under fair weather conditions and optimal manoeuver for rose shrimp, as indicated by the remarks of the skipper. The final data set comprises 1780 hauls (corresponding to 845 days), including start and end location of the haul (GPS), duration of the haul (min), catch $(\mathrm{kg})$ and size composition (CL, standard carapace length in $\mathrm{mm}$ ). The catch of rose shrimp is traditionally divided and marketed under 3 categories: small $(<24 \mathrm{~mm} C L$, comprising juveniles of both sexes and males, which are smaller than 
Table 1 Summary statistics of the fishing activity by the commercial boat sampler. SER: Serola (slope); CPN: Can Pere Negre (slope/canyon); MER: Merenguera (canyon); SSA: Sant Salvador (canyon); these are the local names of the 4 selected sampling areas (fishing grounds). ALL: combination of the 4 sampling areas

\begin{tabular}{|lccccc|}
\hline & SER & CPN & MER & SSA & ALL \\
\hline Total number of days visited & 348 & 160 & 215 & 122 & 845 \\
Total number of hauls & 502 & 241 & 671 & 366 & 1780 \\
Catch (kg h-1, mean \pm 2 SE) & $6.31 \pm 0.42$ & $7.37 \pm 0.94$ & $9.93 \pm 0.54$ & $10.89 \pm 0.70$ & $8.69 \pm 0.31$ \\
\hline
\end{tabular}

females in this sexually dimorphic species), medium (24 to $45 \mathrm{~mm} \mathrm{CL}$, comprising mainly 2 yr old females and a small fraction of large males), and large (>45 $\mathrm{mm}$ $\mathrm{CL}$, consisting entirely of adult females). The size intervals and categories by sex were studied by Sardà \& Demestre (1987). Table 1 summarises the structure of the 10 yr data set. The catch data were standardised to CPUE (catch per unit effort, $\mathrm{kg} \mathrm{h}^{-1}$ ), which is used as an index of abundance.

The preliminary analysis also showed that the activity of the fishing boat followed a definite seasonal pattern along the $10 \mathrm{yr}$ study period. Accordingly, the final data set was organised as a notional study year, lumping data for each month, for each of the main fishing grounds (accounting for over $95 \%$ of the total hauls): Serola (slope), Can Pere Negre (slope/canyon), Merenguera (canyon) and Sant Salvador (canyon).

During the period of the commercial sampling, a parallel and complementary experimental trawl sampling was performed to quantify the internal population structure of Aristeus antennatus inside the canyon and on the slope. The experimental sampling was conducted aboard the RV 'García del Cid' (38 m length, $1200 \mathrm{hp}$ ) in spring and autumn 1991 and in winter and summer 1992. The objective of the experimental sampling was to sample adequately the 4 seasons of the year and investigate the possible bias introduced by fishing interests in the commercial data set. The trawl used had the same characteristics as the commercial trawl, including mesh size. The cod-end liner was fitted with a $12 \mathrm{~mm}$ stretched mesh size to evaluate the catch efficiency on juveniles. Two adjacent fishing grounds were selected for the experimental surveys: Abissinia (slope) and Merenguera (canyon). The biological data collected in these surveys were: number and weight of individuals, CL, sex and stage of gonadal maturity, according to the gonadal stages defined by Demestre \& Fortuño (1992). The data obtained were analysed for size frequency distribution, comparing the 2 habitats. The size frequency distribution was analysed separately by sexes, given that $A$. antennatus is markedly sexually dimorphic, females being larger than males.

One-way analysis of variance (ANOVA) was performed on catch data by size categories and by fishing grounds to detect significant differences $(\alpha=0.05$; Berenson et al. 1983). A post hoc Scheffé test was employed to isolate the significant effects of the ANOVA (Berenson et al. 1983). The KolmogorovSmirnov test was performed on pairs of size frequency distributions by sex to detect significant differences $(\alpha=0.01$; Sokal \& Rohlf 1969) in the shape of the histograms. For those pairs of size frequencies that were significantly different, the difference in the mean size was tested by Student's t-test (Sokal \& Rohlf 1969).

\section{RESULTS}

The spatio-temporal pattern of the fishing activity (defined as days working over a given fishing area) over the 4 selected fishing grounds is presented in Fig. 2. The fishing activity was centered on the Serola grounds between February and May. In May and June the bulk of the activity shifted towards Can Pere Negre. From June to October, fishing was more important in Merenguera canyon and from September to March, the boat turned to Sant Salvador canyon.

The monthly catch (Fig. 3) closely followed this pattern. In winter (January and February) the highest catch (around $10 \mathrm{~kg} \mathrm{~h}^{-1}$ ) was obtained in the canyon fishing grounds (Merenguera and Sant Salvador), while the occasional visits to Serola (slope) yielded about $5 \mathrm{~kg} \mathrm{~h}^{-1}$. In spring (March to June), increasing and sustained catches on Serola and Can Pere Negre are probably the reason of the shift of the activity towards slope areas easier to work on. The occasional visits to the canyon fishing grounds yielded negligible abundance (except in April in Merenguera). In summer and early autumn, the catch was zero on the slope (Serola), while catch was still sustained on Can Pere Negre (intermediate characteristics between slope and canyon). In late autumn and winter, the resource seemed to disappear from Can Pere Negre, while it recovered in Merenguera canyon, but it was particularly high in the canyon areas.

Thus, the mobility pattern of the fishing activity closely matches the availability of rose shrimp and the trawlers can be said to 'follow' the shrimp, which is more abundant from late winter to summer over slope 


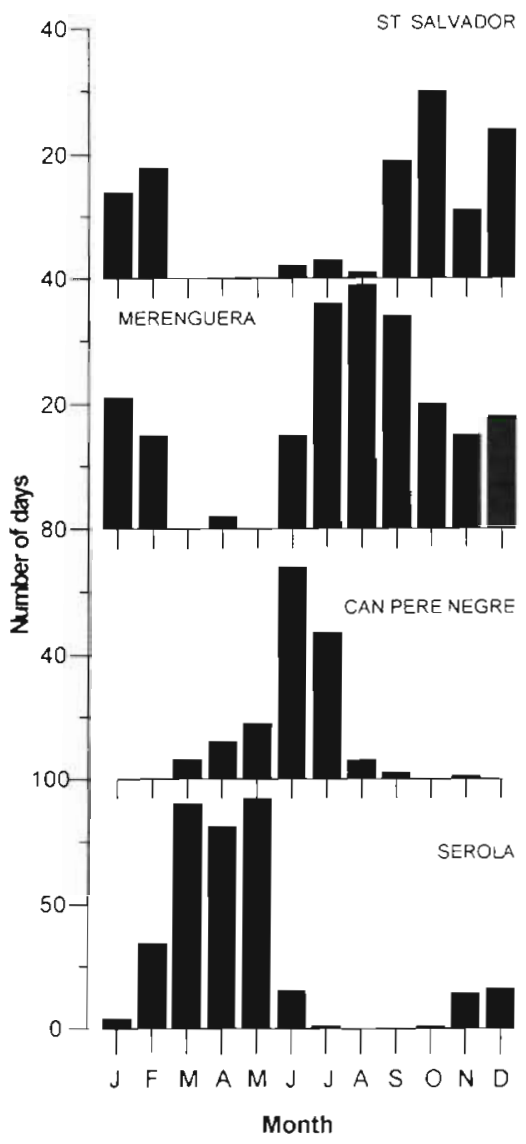

Fig. 2. Evolution of the sampling effort (number of days visiting a given sampling area) by the commercial boat sampler during the 10 yr period. Number of visits are pooled within a notional year

areas and more abundant from late summer to early winter in the canyons. This is made clear in Fig. 4, where the pooled catch over the 4 fishing grounds is represented. The abundance is fairly constant along the year (around $10 \mathrm{~kg} \mathrm{~h}^{-1}$ ) because the fishers adapt to the predictable fluctuations of the resource, thus ensuring themselves a certain constancy in their earnings.

The ANOVA results of the rose shrimp abundance in space by categories is presented in Table 2 . The size

Table 2. Aristeus antennatus. Mean abundance $\left(\mathrm{kg} \mathrm{h}^{-1}\right)$ of size categories in the 4 sampling areas. All categories differed significantly in a 1 -way ANOVA, at the $\alpha$-level 0.05 . Abbreviations as in Table 1

\begin{tabular}{|lcccc|}
\hline & SER & CPN & MER & SSA \\
\hline Small & 0.902 & 0.543 & 1.900 & 4.412 \\
Medium & 1.042 & 0.589 & 3.457 & 3.244 \\
Large & 3.148 & 3.624 & 4.324 & 3.631 \\
\hline
\end{tabular}

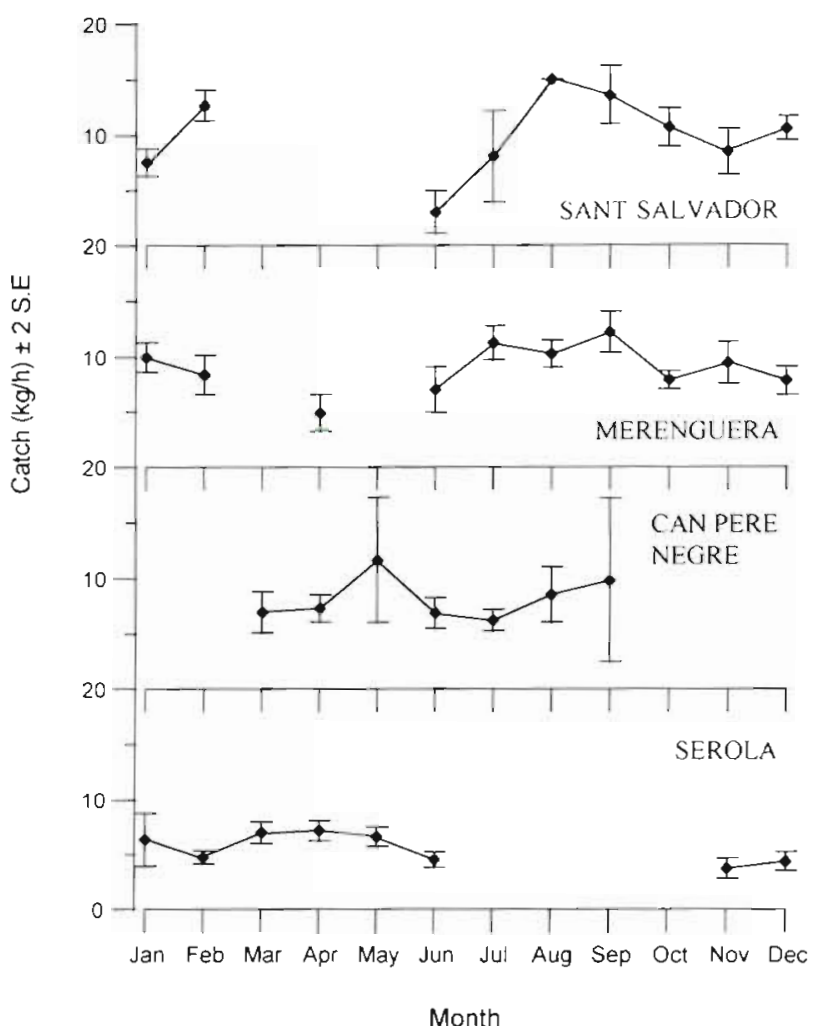

Fig. 3. Ansteus antennatus. Evolution of the rose shrimp abundance (in catch per unit effort) on the 4 main fishing grounds during the 10 yr sampling period, pooled over the notional year

composition of the catch varied according to the habitats. In Serola and Can Pere Negre (slope facies) large shrimp abundance was over $3 \mathrm{~kg} \mathrm{~h}^{-1}$ while small and medium shrimp represented $1 \mathrm{~kg} \mathrm{~h}^{-1}$ or less. In Merenguera and Sant Salvador canyons the mean abundance was comparable to that of the slope fishing grounds, but the fraction of small plus medium shrimp was dominant, and more so in Sant Salvador canyon.

A post hoc Scheffé test among categories (Table 3) illustrates that the spatial factor was more important for smaller shrimp than for larger shrimp. Thus, the abundance of small and medium shrimp was significantly different between slope and canyon fishing grounds, while the abundance of large shrimp was different only between Serola and Merenguera canyon. Also, large shrimp caught by the sampling boat on each fishing ground (Table 4) constituted 61.7 and $74.3 \%$ of total shrimp on the slope areas and less than $50 \%$ in canyons. These results indicate that a component of population structure (small/large shrimp) must be added to the spatial fluctuation of shrimp shown in Fig. 3. Considering that Aristeus antennatus males are smaller than females, the high abundance of small and medium shrimp in the canyon areas is in part due to 
Table 3. Aristeus antennatus. Post hoc Scheffé test among categories of Table 2. Abbreviations as in Table 1. ns: not significant. Significance: $\cdots p<0.01, \cdots p<0.001$

\begin{tabular}{|c|c|c|c|}
\hline & SER & $\mathrm{CPN}$ & MER \\
\hline \multicolumn{4}{|c|}{ Small } \\
\hline CPN & ns & & \\
\hline MER & $\cdots$ & $\cdots$ & \\
\hline SSA & $\cdots$ & $\cdots$ & $\cdots$ \\
\hline \multicolumn{4}{|c|}{ Medium } \\
\hline CPN & ns & & \\
\hline MER & $\cdots$ & $\cdots$ & \\
\hline SSA & $\cdots$ & $\because$ & ns \\
\hline \multicolumn{4}{|c|}{ Large } \\
\hline CPN & ns & & \\
\hline MER & $\cdots$ & ns & \\
\hline SSA & ns & ns & $\mathrm{ns}$ \\
\hline
\end{tabular}

Table 4. Aristeus antennatus. Total kg caught by the commercial boat sampler by size categories. Abbreviations as in Table 1

\begin{tabular}{|lccccc|}
\hline & SER & CPN & MER & SSA & ALL \\
\hline Small (\%) & 18.0 & 11.9 & 19.9 & 38.3 & 23.3 \\
Medium(\%) & 20.3 & 13.8 & 33.7 & 28.0 & 25.7 \\
Large (\%) & 61.7 & 74.3 & 46.4 & 33.7 & 51.1 \\
Total (tonnes) & 4.14 & 0.89 & 2.86 & 3.21 & 11.10 \\
\hline
\end{tabular}

the higher occurrence of males in those areas (Sardà et al. $1994 \mathrm{~b})$.

Table 5 shows the summary data corresponding to the experimental trawl sampling. Females were dominant in the samples. The samples with a low number of individuals were also used in the analyses, given that the low abundance of shrimp results from the season of the year and the habitat sampled and is not a problem of inadequate sampling. The size frequencies obtained are thus representative of the population remaining on the fishing grounds (Sardà et al. 1994b).

Histograms were constructed for each haul from the size frequencies obtained in the sampling for each sex

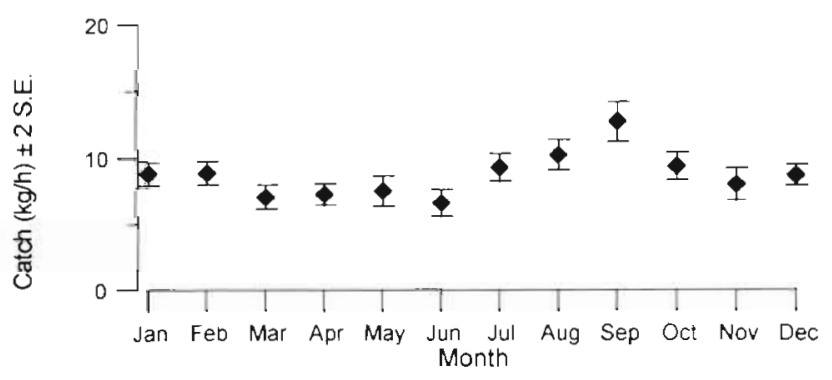

Fig. 4. Aristeus antennatus. Evolution of the rose shrimp abundance (in catch per unit effort) along the notional year, pooling data for all sampling areas

separately, because Aristeus antennatus is a sexually dimorphic species. Each histogram was compared with all other histograms for the same sex (Table 6).

The size frequencies of females from the slope (odd codes) were not significantly different (at the level of $\alpha<0.01$ ) for different seasons of the year (Table 6). The size frequencies of females corresponding to the canyon samples (even codes) differed for the pairs S2-A4, S2-Su8, A4-Su8 and W6-Su8. The mean of the size frequency for sample Su8 was significantly larger than that of all other samples, i.e. females found in summer were larger than in other seasons of the year. However, the mean size of females was smaller in the canyon than on the slope, except for pair S1-Su8.

For male samples corresponding to the slope lodd code), differences were significant for the pairs A3-Su7 and W5-Su7 (Table 6). Sample Su7 (slope) corresponds to summer, when the smallest males were found on the slope. The largest males were observed in sample W5 (slope), corresponding to winter. In the canyon, in autumn and winter, the number of males in the samples was also higher than in spring and summer samples.

As reported in other works (Sardà \& Demestre 1987 , Tobar \& Sardà 1987), the mean size of females was always larger than that of males for any season and location. Further, females were always more abundant than males in the catch, specially in summer, when

Table 5. Aristeus antennatus. Experimental trawl sampling for the analysis of population structure in the study area. Code: even numbers correspond to canyon samples, odd to slope samples

\begin{tabular}{|c|c|c|c|c|c|c|}
\hline Code & Season & Date & Mean depth (m) & No. of males & No. of females & Sex ratio $(\%)$ \\
\hline 1 & Spring & 23 Apr 1991 & 600 & 205 & 521 & 39.3 \\
\hline 2 & Spring & 23 Apr 1991 & 400 & 126 & 867 & 14.5 \\
\hline 3 & Autumn & 09 Dec 1991 & 600 & 15 & 28 & 53.6 \\
\hline 4 & Autumn & 09 Dec 1991 & 450 & 158 & 660 & 23.9 \\
\hline 5 & Winter & 12 Mar 1992 & 550 & 144 & 314 & 45.9 \\
\hline 6 & Winter & 12 Mar 1992 & 450 & 17 & 110 & 15.5 \\
\hline 7 & Summer & 26 Jul 1992 & 600 & 4 & 371 & 1.1 \\
\hline 8 & Summer & 26 Jul 1992 & 400 & 26 & 1130 & 2.32 \\
\hline
\end{tabular}


Table 6. Aristeus antennatus. Pair comparison of histograms for samples obtained in the experimental trawling by sexes S: spring; Su: summer; A: autumn; W: winter. Slope: odd codes; canyon: even codes. K-S: Kolmogorov-Smirnov test ("p <0.01); ds: significant differences for $M$ (males) and/or $F$ (females). $X$ : mean of the first tistogram compared (left code); $Y$. mean of the second histogram compared (right code). $t$ : $t$-test values for mean comparisons only were considered when K-S was significant

\begin{tabular}{|c|c|c|c|c|c|c|c|c|c|c|c|c|c|}
\hline \multirow{3}{*}{$\begin{array}{l}\text { Samples } \\
\text { compared }\end{array}$} & \multirow[t]{3}{*}{ ds } & \multicolumn{6}{|c|}{ Females } & \multicolumn{6}{|c|}{ Males } \\
\hline & & \multicolumn{2}{|c|}{ Frequencies, K-S test } & \multicolumn{4}{|c|}{ Means, Student's $t$-test } & \multicolumn{2}{|c|}{ Frequencies, $\mathrm{K}-\mathrm{S}$ test } & \multicolumn{4}{|c|}{ Means, Student's t-test } \\
\hline & & d & $\mathrm{p}$ & $X$ & Y & $t$ & $\mathrm{p}$ & $d$ & $\mathrm{p}$ & $x$ & $Y$ & $t$ & $p$ \\
\hline $\mathrm{S} 1-\mathrm{S} 2$ & $M$ & 0.2713 & 0.0543 & 30.76 & 27.99 & 2.3303 & 0.0199 & 0.5803 & $0.0009^{\circ}$ & 24.94 & 20.41 & 4.2443 & $0.0000^{\circ}$ \\
\hline $\mathrm{S} 1-\mathrm{A} 3$ & & 0.1749 & 0.4417 & 30.76 & 32.50 & -0.9313 & 0.3519 & 0.1626 & 0.9216 & 24.94 & 26.00 & -0.9928 & 0.3211 \\
\hline $\mathrm{S} 1-\mathrm{A} 4$ & & 0.1993 & 0.2846 & 30.76 & 32.68 & -1.0534 & 0.2923 & 0.1390 & 0.9794 & 24.94 & 24.19 & 0.8305 & 0.4063 \\
\hline S1-W5 & & 0.2872 & 0.0351 & 30.76 & 35.38 & -3.0994 & $0.0020^{\circ}$ & 0.3452 & 0.1290 & 24.94 & 26.95 & -2.3441 & 0.0192 \\
\hline S1-W6 & & 0.2334 & 0.1384 & 30.76 & 28.18 & 1.8672 & 0.0620 & 03545 & 0.1112 & 24.94 & 23.00 & 2.0076 & 0.0448 \\
\hline S1-Su7 & & 0.3105 & 0.0178 & 30.76 & 34.16 & -2.3852 & 0.0172 & 04049 & 0.046 .1 & 24.94 & 23.00 & 1.8894 & 0.0590 \\
\hline S1-Su8 & MF & 0.3722 & $0.0023^{\circ}$ & 30.76 & 36.05 & -3.8749 & $0.0001^{\circ}$ & 0.5995 & $0.0005^{\circ}$ & 24.94 & 21.00 & 3.5733 & $0.0004^{\circ}$ \\
\hline $\mathrm{S} 2-\mathrm{A} 3$ & MF & 0.4375 & $0.0002^{*}$ & 27.99 & 32.50 & -2.6868 & $0.0073^{\circ}$ & 0.6730 & $0.0001^{\circ}$ & 20.41 & 26.00 & -4.6701 & $0.0000^{\circ}$ \\
\hline $\mathrm{S} 2-\mathrm{A} 4$ & MF & 0.3370 & $0.0077^{\circ}$ & 27.99 & 32.68 & -2.8864 & $0.0040^{\circ}$ & 0.4933 & $0.0074^{\circ}$ & 20.41 & 24.19 & -3.6112 & $0.0003^{\circ}$ \\
\hline S2-W5 & MF & 0.5479 & $0.0000^{\circ}$ & 27.99 & 35.38 & -5.9271 & $0.0000^{\circ}$ & 0.8136 & $0.0000^{\circ}$ & 20.41 & 26.95 & -6.4577 & $0.0000^{\circ}$ \\
\hline S2-W6 & & 0.1348 & 0.7652 & 27.99 & 28.18 & -0.1700 & 0.8651 & 0.3077 & 0.2264 & 20.41 & 23.00 & -2.3490 & 0.0189 \\
\hline S2-Su7 & $\mathrm{F}$ & 0.5818 & $0.0000^{\circ}$ & 27.99 & 34.16 & -5.2776 & $0.0000^{\circ}$ & 0.3730 & 0.0815 & 20.41 & 23.00 & -2.2414 & 0.0251 \\
\hline S2-Su8 & $F$ & 0.6435 & $0.0000^{\circ}$ & 27.99 & 36.05 & -7.3611 & $0.0000^{\circ}$ & 0.2081 & 0.7019 & 20.41 & 21.00 & -0.4859 & 0.6271 \\
\hline $\mathrm{A} 3-\mathrm{A} 4$ & & 0.1596 & 0.5603 & 32.50 & 32.68 & -0.0809 & 0.9355 & 0.2675 & 0.3829 & 26.00 & 24.19 & 1.7223 & 0.0853 \\
\hline A3-W5 & & 0.2082 & 0.2388 & 32.50 & 35.38 & -1.5126 & 0.1303 & 0.2167 & 0.6526 & 26.00 & 26.95 & -0.9362 & 0.3491 \\
\hline A3-W6 & F & 0.4083 & $0.0006^{\circ}$ & 32.50 & 28.18 & 2.3727 & 0.0178 & 0.4471 & 0.0201 & 26.00 & 23.00 & 2.7093 & $0.0068^{\circ}$ \\
\hline A.3-Su7 & M & 0.2068 & 0.2457 & 32.50 & 34.16 & -0.8969 & 0.3700 & 0.5334 & $0.0029^{\circ}$ & 26.00 & 23.00 & 2.5855 & $0.0098^{\circ}$ \\
\hline A.3-Su8 & M & 0.2805 & 0.0423 & 32.50 & 36.05 & -1.9654 & 0.0495 & 0.6922 & $0.0000^{\circ}$ & 26.00 & 21.00 & 4.0702 & $0.0000^{\circ}$ \\
\hline$A 4-W 5$ & $M$ & 0.2819 & 0.0408 & 32.68 & 35.38 & -1.4576 & 0.1450 & 0.4842 & $0.0091^{\circ}$ & 24.19 & 26.95 & -3.3081 & $0.0010^{\circ}$ \\
\hline A4-W6 & & 0.2939 & 0.0290 & 32.68 & 28.18 & 2.5400 & 0.0112 & 0.2674 & 0.3834 & 24.19 & 23.00 & 1.2619 & 0.2069 \\
\hline A4-Su 7 & & 0.2829 & 0.0396 & 32.68 & 34.16 & -0.8244 & 0.4100 & 0.2658 & 0.3906 & 24.19 & 23.00 & 1.1844 & 0.2361 \\
\hline A4-Su8 & $M$ & 0.3542 & $0.0043^{\circ}$ & 32.68 & 36.05 & -1.9228 & 0.0547 & 0.5529 & $0.0018^{\circ}$ & 24.19 & 21.00 & 2.9461 & $0.0033^{\circ}$ \\
\hline W5-W6 & MF & 0.51 .28 & $0.0000^{\circ}$ & 35.38 & 28.18 & 5.0261 & $0.0000^{\circ}$ & 0.5777 & $0.0009^{\circ}$ & 26.95 & 23.00 & 4.3676 & $0.0000^{\circ}$ \\
\hline W5-Su 7 & $M$ & 0.1188 & 0.8798 & 35.38 & 34.16 & 0.8253 & 0.4092 & 0.7501 & $0.0000^{\circ}$ & 26.95 & 23.00 & 4.0786 & $0.0000^{\circ}$ \\
\hline W5-Su8 & $M$ & 0.0956 & 0.9785 & 35.38 & 36.05 & -0.4763 & 0.6338 & 0.7382 & $0.0000^{\circ}$ & 26.95 & 21.00 & 5.6713 & $0.0000^{\circ}$ \\
\hline W6-Su7 & F & 0.5250 & $0.0000^{\circ}$ & 28.18 & 34.16 & -4.3804 & $0.0000^{\circ}$ & 0.1764 & 0.8665 & 23.00 & 23.00 & -0.0001 & 1.000 \\
\hline W6-Su8 & $\mathrm{F}$ & 0.5957 & $0.0000^{\circ}$ & 28.18 & 36.05 & -6.0433 & $0.0000^{\circ}$ & 0.5157 & $0.0044^{\circ}$ & 23.00 & 21.00 & 1.7577 & 0.0790 \\
\hline Su7-Su 8 & & 0.1101 & 0.9280 & 34.16 & 36.05 & -1.4023 & 0.1612 & 0.5384 & $0.0025^{\circ}$ & 23.00 & 21.00 & 1.6815 & 0.0928 \\
\hline
\end{tabular}

almost $100 \%$ of the samples were made up of females (Table 5). In the canyon samples, the proportion of males was always smaller than $25 \%$, while on the slope the proportion was close to $50 \%$ in autumn and winter (although the number of samples was relatively low in autumn; Table 5).

\section{DISCUSSION}

Tagging and tracking technıques offer direct and exact information on the mobility of decapod crustaceans. These techniques have been successfully applied to shallow-water decapods, such as prawns (García \& Le Reste 1987), lobsters (Campbell 1986) or majids (Hines et al. 1995). All these species have in common a heavily calcified shell, long intermoult periods and resistance to handling, and they are usually caught in shallow waters by pots.

Deep-sea shrimps such as Aristeus antennatus present difficulties for the application of direct systems to assess mobility. They are caught by bottom trawls at great depth and most specimens arrive dead to the deck, sometimes with a damaged shell due to its fragility. Tagging experiments performed in the pandalid shrimp Pandalus borealis (Skúladóttir 1985) resulted in a low recapture percentage (2.8\%) during 14 mo. Thus the information obtained from commercial fishing boats over long time periods, when correctly treated and analysed, is more efficient and less expensive in the study of deep-water shrimp mobility.

The pattern that emerges from the combination of the 2 studies presented here is the following (Fig. 5): rose shrimp abundance is higher on the slope in spring and summer, while its abundance is higher from late summer to early winter in the canyons. Further, this space-time dynamics is complicated by the fact that small and medium shrimp are found in the canyons at higher abundances than larger shrimp and this fraction of the population is composed mainly of males and juveniles. Canyons can be seen as the recruitment areas of individuals to the population, as shown for European hake (Merluccius merluccius; Stefanescu et al. 1994) and also for crustacean decapods and other invertebrates (Sardà et al. 1994a). Thus, Aristeus antennatus is a deep-water decapod species with 
important spatial and temporal sex and size segregation. In this sense, it is comparable to other decapod crustaceans, such as shallow-water penaeid shrimps (Garcia \& Le Reste 1987), deep species of Plesionika (Company \& Sardà 1997) or majid crabs (González-Gurriarán \& Freire 1994, Stevens et al. 1994, Hines et al. 1995) dwelling on the continental slope. Benthic decapod species undertaking large-scale migrations have rarely been reported in the deep sea (Abelló \& Macpherson 1991).

However, there remains the problem that large mature females are mainly found in summer over the open slope, when males are very rare. It is in spring and summer that females undergo gonadal riping and mate, but it is mainly in winter and early spring that males are relatively abundant over slope areas, which would make possible physical contact between the sexes. After mating, rose shrimp females carry the spermatophores for some months in the thelycum, thus storing sperm that can be used later to fertilise eggs in the absence of males (Demestre \& Fortuño 1992). This strategy is not unlike that reported for deep-water gastropod molluscs, where sperm is stored internally (Gage \& Tyler 1992, p. 318) or in shallow-water decapod crustaceans (Bauer 1986 Elner \& Beninger 1995). This strategy would be advantageous for species showing sexual segregation and/or low densities which make physical contact difficult or alternatively, mating aggregations exist in Aristeus antennatus (as in majid crabs; Stevens et al. 1994) but have not been accessed by the trawling sampling gear

Thus, the reproductive behaviour related to fertilisation is not yet well understood in this species. Either males are present on the slope in spring and summer but not available to the trawl or the few existent males are responsible for a large number of matings. Personal observations by one of the authors (F.S.) fishing above the sea-floor with a mid-water trawl did not yield any evidence for vertical displacements of Aristeus antennatus in the water column. On the other hand, Cartes \& Sardà (1989) and Sardà \& Cartes (1997) studied the stomach contents of male and juvenile $A$. antennatus and found that they feed totally on benthic prey. Both the experimental mid-water trawling and the feeding studies point to a benthic habitat for all size classes and sexes in $A$. antennatus.
On the other hand, our results would indicate that mating, gonadal maturity, spawning and fertilisation take place in slope areas and canyons, which are the centres of juvenile concentration (Sardà \& Cartes 1997).

The mobility pattern described here on the basis of a 10 yr catch record confirms the hypothesis put forward by Sardà et al. (1994b) working on a 1 yr data set. The actual bio-ecological mechanisms governing such space-time dynamics remain poorly understood for Aristeus antennatus, but some possible mechanisms can be considered, on the basis of what is known of the ecology and biology of this species and its role in deepwater ecosystems.

Cartes \& Sardà (1989) found differences in the diet composition of the various rose shrimp size classes, which exploit different infaunal resource levels. Results from studies on the feeding ecology of other deep-water animals showed a low intraspecific and interspecific dietary overlap (Macpherson 1981, Hopkins \& Baird 1985, Blaber \& Bulman 1987). These results are interpreted by some authors as indicating that marine communities in deep-water habitats exhibit low levels of competition and predation (Grassle \& Sanders 1973, Cartes \& Sardà 1989). It is known also that population structure tends to adopt a form that will minimise interspecific competition (Ameyaw-Akumfi \& Hughes 1987) or intraspecific 
competition between size classes (Keast 1978) in order to optimise energy utilisation through balanced partitioning of available resources. This is often responsible for size segregation, or for sex segregation when size is sex-dependent (Peters \& Grubb 1983). Cartes (1994), studying seasonal aspects of the rose shrimp diet composition, found that between 400 and $1000 \mathrm{~m}$ the diet composition varied seasonally, but below $1000 \mathrm{~m}$ no clear seasonality was found. The $1000 \mathrm{~m}$ transition zone coincides with a faunal change in the prey items of Aristeus antennatus (Cartes 1994) and also with a change in the population structure of rose shrimp (Sardà \& Cartes 1993a, b); below $1000 \mathrm{~m}$, the $A$. antennatus population is composed of males and females in equal proportions and smaller mean sizes.

Cartes (1994) also found that the food items used by rose shrimp in the canyons were different from slope food items. Canyons have characteristics that distinguish them from the open slope (Haedrich et al. 1975 , 1980), such as higher productivity and regular influx of organic matter, and a higher abundance of deposit feeders. In the canyons, rose shrimp diet relied more heavily on endobenthic deposit feeders (Cartes 1994). which are easier to capture for small and juvenile Aristeus antennatus when compared with benthopelagic prey, which becomes more important as a prey item in larger shrimp. Thus, the sex and size segregation observed in rose shrimp populations shallower than $1000 \mathrm{~m}$ could be due to seasonally and spatially varying food resources and ecological partitioning of these resources to minimise intraspecific competition and maximise energy utilisation.

Most studies on reproduction of deep-water decapods did not show evidence of seasonality (see Gage \& Tyler 1992, p. 306 for discussion), although in Aristeus antennatus there is evidence of this (Orsi Relini \& Relini 1979, Sardà \& Demestre 1987, Demestre \& Fortuño 1992). The factor(s) that trigger the initiation of the reproductive cycle in deep-sea animals are thought to be related to the sinking from the surface of seasonally produced organic matter (De Bovée et al. 1990, Féral et al. 1990, Gage \& Tyler 1992, p. 316-317. Starr et al. 1994) Thus the effects of the seasonal overlying production regime in the NW Mediterranean can be detected down to $1000 \mathrm{~m}$, at least, for $A$. antennatus.

In conclusion, our results show the existence of a mobility pattern in Aristeus antennatus populations. The internal population structure and abundance of rose shrimp vary over different geomorphological habitats and depth ranges. The phenomenon studied is persistent in time and could probably be extrapolated to other areas in the Mediterranean and eastern Atlantic where $A$. antennatus is found.

\section{LITERATURE CITED}

Abelló P, Macpherson E (1991) Distribution patterns and migration of Lithodes ferox (Filhol) (Anomura: Lithodidae) off Namibia. J Crustac Biol 11:261-268

Ameyaw-Akumf $C_{1}$. Hughes RN (1987) Behaviour of Carcinus maenas feeding on large Mytilus edulis. How do they assess the optimal diet? Mar Ecol Prog Ser 38:213-216

Bauer RT (1986) Phylogenetic trends in sperm transfer and storage complexity in decapod crustaceans. J Crustac Biol 6:313-325

Berenson ML, Levine DM, Goldstein M (1983) Intermediate statistical methods and applications. Prentice-Hall Inc, Englewood Cliffs, NJ

Bianchini MI, Ragonese S (1994) Life cycles and fisheries of the deep-water red shrimps Aristeomorpha foliacea and Aristeus antennatus. NTR-ITPP Spec Publ 3:1-87

Blaber SJ, Bulman CM (1987) Diets of fishes of the upper continental slope of eastern Tasmania: content, calorie values, dietary overlap and trophic relationships. Mar Biol 95 $345-357$

Campbell A (1986) Migratory movements of ovigerous lobsters, Homarus americanus, tagged off Grand Manan, Eastern Canada. Can J Fish Aquat Sci 43:2197-2205

Cartes JE (1994) Influence of depth and season on the diet of the deep-water aristeid Aristeus antennatus along the continental slope $(400$ to $2300 \mathrm{~m}$ ) in the Catalan Sea (Western Mediterranean). Mar Biol 120:639-648

Cartes JE, Sarda F (1989) Feeding ecology of the deep-water penaeid crustacean Aristeus antennatus (Risso, 1816) in the Mediterranean Sea. Mar Ecol Prog Ser 54:229-238

Cartes JE, Sardà F (1992) Abundance and diversity of decapod crustaceans in the deep Catalan Sea (Western Mediterranean). J Nat Hist 26:1305-1323

Cartes JE, Sarda F (1993) Zonation of the deep-sea decapod fauna in the Catalan Sea (Western Mediterranean). Mar Ecol Prog Ser 94:27-34

Company JB, Sardà F (1997) Reproductive patterns and population characteristics in five deep-water shrimps in the Western Mediterramean along a depth gradient (150$1100 \mathrm{~m}$ ). Mar Ecol Prog Ser 148:49-58

De Bovée F, Guidi LD, Soyer J (1990) Quantitative distribution of deep-sea macrobenthos in the northwestern Mediterranean (Gulf of Lion). Cont Shelf Res 10:1123-1146

Demestre M, Fortuño JM (1992) Reproduction of the deepwater shrimp Aristeus antennatus (Decapoda: Dendrobranchiata). Mar Ecol Prog Ser 84:41-51

Demestre M. Lleonart J (1993) The population dynamics of Aristeus antennatus (Decapoda: Dendrobranchiata) in the Northwestern Mediterranean. Scientia Mar 57(2-3): 183-189

Elner RW, Beninger PG (1995) Multiple reproductive strategies in snow crab, Chionoecetes opilio: physiological pathways and behavioural plasticity. J Exp Mar Biol Ecol 193: $93-112$

Féral JP, Ferrand JG, Guille A (1990) Macrobenthic physiological responses to environmental fluctuations: the reproductive cycle and enzymatic polymorphism of a eurybathic sea-urchin on the northwestern Mediterranean continental shelf and slope. Cont Shelf Res 10:1147-1155

Gage JD. Tyler PA (1992) Deep-sea biology: a natural history of organisms at the deep-sea floor. Cambridge University Press, London

García S, Le Reste L (1987) Ciclos vitales, dinámica, explotación y ordenación de las poblaciones de camarones peneidos costeros. FAO Doc Tec Pesca 203:1-180

González-Gurriarán E, Freire J (1994) Movement patterns 
and habitat utilization in the spider crab Maja squinado (Harbst) (Decapoda, Majidae) measured by ultrasonic telemetry. J Exp Mar Biol Ecol 184:269-291

Grassle JF, Sanders HL (1973) Life histories and the role of disturbance. Deep Sea Res 20:643-659

Haedrich RL, Rowe GT, Polloni PT (1975) Zonation and faunal composition of epibenthic populations on the continental slope south of New England. J Mar Res 33:191-212

Haedrich RL, Rowe GT, Polloni PT (1980) The megabenthic fauna in the deep sea south of New England. USA. Mar Biol 57:165-179

Hines AH, Wolcott TG, González-Gurriarán E, GonzálezEscalante JL, Freire J (1995) Movement patterns and migrations in crabs: telemetry of juvenule and adult behaviour in Callinectes sapidus and Maja squinado. J Mar Biol Assoc UK 75:27-42

Hopkins TH, Baird RC (1985) Feeding ecology of four hatchet fishes (Sternoptychidae) in the eastern Gulf of Mexico. Bull Mar Sci 36(2):260-277

Keast A (1978) Feeding interrelations between age-groups of pumpkinseed (Lepomis gibbosus) and comparisons with bluegill (L. macrochirus). J Fish Res Bd Can 35:12-27

Macpherson E (1981) Resource partitioning in a Mediterranean demersal fish community. Mar Ecol Prog Ser 4:183-193

Maynou F, Cartes JE (1997) Field estimation of daily ration in the deep-sea shrimp Aristeus antennatus (Crustacea: Decapoda) in the western Mediterranean. Mar Ecol Prog Ser 153:191-196

Orsi Relini L, Relini G (1979) Pesca e riproduzione del gambero rosso Aristeus antennatus (Decapoda: Penaeidae) nel Mar Ligure. Quad Civica Staz Idrobiol Milano 7:39-62

Ouellet $P$, Lefaivre D (1994) Vertical distribution of northern shrimp (Pandalus borealis) larvae in the Gulf of Saint Lawrence: implications for trophic interactions and transport. Can J Fish Aquat Sci 51(1):123-132

Peters WD, Grubb JC Jr (1983) An experimental anlysis of sex-specific foraging in the downy woodpecker Picoides pubescens. Ecology 64:1437-1443

Ragonese S, Bianchini M (1992) Stima dei parametri di crescita di Aristeus antennatus nel Canale di Sicilia. Oebalia 17 (Suppl):101-107

Ragonese S, Bianchini M (1996) Growth, mortality and yield per recruit of the deep-water shrimp $A$. antennatus of the Strait of Sicily (Mediterranean Sea). Fish Res 26:125-137

Relini G, Orsi Relini L (1987) The decline of red shrimp stocks in the Gulf of Genoa. Inv Pesq 51 (Suppl 1):245-260

Editorial responsibility: Otto Kinne (Editor),

Oldendorf/Luhe, Germany
Sarda F (1993) Bio-ecological aspects of the decapod crustacean fisheries in the Western Mediterranean. Aquat Luv Res 6:299-306

Sardà F, Cartes JE (1993a) Distribution, abundance and selected biological aspects of Aristeus antennatus (Decapoda: Aristeidae) in deep-water habitats in the NW Mediterranean. BIOS Thessaloniki 1(1):59-73

Sardà $F$, Cartes JE (1993b) Relationship between size and depth in decapod crustacean populations on the deep slope in the Western Mediterranean. Deep Sea Res 40 $(11-12): 2389-2400$

Sardà F, Cartes JE (1997) Morphological features and ecological aspects of early juvenile specimens of the aristeid shrimp Aristeus antennatus (Risso, 1816). Mar Freshwater Res 48:73-77

Sarda F, Cartes JE, Company JB (1994a) Spatio-temporal variations in megabenthos abundance in three different habitats of the Catalan deep-sea (Western Mediterranean). Mar Biol 120:211-219

Sardà F, Cartes JE, Norbis W (1994b) Spatio-temporal structure of the deep-water shrimp A. antennatus Risso, 1816 (Decapoda: Aristeidae) population in the Western Mediterranean. Fish Bull US 92(3):599-607

Sardà F, Demestre M (1987) Estudio biológico de la gamba Aristeus antennatus (Risso, 1816) en el Mar Catalán (NE de España). Invest Pesq 51(1):213-232

Skúladóttir U (1985) Tagging and recapture results of Pandalus borealis (Kröyer) in Icelandic waters. ICES CM 1985/K:42

Sokal RR, Rohlf FJ (1969) Biometría. H Blume Ediciones, Madrid

Starr M, Therriault JC, Conan GY, Comeau M, Robichaud G (1994) Larval release in a sub-euphotic zone invertebrate triggered by sinking phytoplankton particles. J Plankton Res 16:1137-1147

Stefanescu C, Morales-Nin B, Massutí M (1994) Fish assemblages on the slope in the Catalan sea (Western Mediterranean): influence of a submarine canyon. J Mar Biol Assoc UK 74:499-512

Stevens BG, Haaga JA, Donaldson WE (1994) Aggregative mating of tanner crabs, Chionoecetes bairdi. Can J Fish Aquat Sci 51:1273-1280

Tobar R, Sardà F (1987) Análisis de la evolución de las capturas de gamba rosada Aristeus antennatus (Risso, 1816) en los últimos decenios en Cataluña. lnf Tecn Inst Invest Pesq Barcelona 142:1-20

Submitted: July 24, 1997; Accepted: October 7, 1997

Proofs received from author(s): November 10, 1997 